\title{
EVROPSKÉ ENERGETICKÉ PRÁVO: VYBRANÉ NOVINKY ZIMNÍHO ENERGETICKÉHO BALÍČKU*
}

\author{
JIŘÍ POKORNÝ
}

\begin{abstract}
European Energy Law: Selected Winter Energy Packages
The aim of this article is to briefly introduce the latest results of the European legislative process, the so-called winter package, in particular focusing on active consumers and capacity mechanisms, and put everything in context. At the end of the article there is a brief reflection on the appropriate way of incorporating changes into the Czech legal order and the attitude towards the energy union being built.
\end{abstract}

Keywords: winter energy package; prosumer; aggregation; capacity mechanisms

Klíčová slova: zimní energetický balíček; aktivní spotřebitel; agregace; kapacitní mechanismy

DOI: $10.14712 / 23366478.2019 .32$

\section{1. ÚVOD}

Evropská unie je světovým leaderem v oblasti odpovědného př́stupu k životnímu prostředí, globálním problémům s ním spojeným, klimatickou změnu nevyjímaje a toto vše zohledňuje ve vytvářené legislativě, včetně oblasti energetiky. Tato legislativní činnosti má samozřejmě základ v primárním právu, kdy téma energetiky a životního prostředí jsou obsaženy ve Smlouvě o fungování Evropské unie, konkrétně v hlavě XX. se zabývá životním prostředím a hlava XXI. energetikou. Přestože obě oblasti jsou řazeny mezi sdílené kompetence mezi Unii a členské státy, rozsah normotvorby a přijímání pro státy závazných dokumentů (jako jsou rozhodnutí Komise), v oblasti energetiky jednoznačně bobtná a rychlost přijímání aktů se zvyšuje. Vzhledem k představenému projektu energetické unie a přijatým koncepčním dokumentům ${ }^{1}$, toto do jisté míry pochopitelné, byt' př́stup členský států $\mathrm{k}$ otázce dalšího stupně integrace v energetice nejednotný. Tento př́stup si autor dovoluje shrnout jako: „Všichni chtějí bonusy, které energetická unie nabízí, nikdo si nechce nechat zasahovat

* Tento př́íspěvek byl vytvořen s pomocí prostředků alokovaných v programu Progres Q02. Základem článku je př́spěvek přednesený na konferenci Mílniky práva v stredoeurópskom priestore $2019 \mathrm{v}$ rámci sekce Environmentálného práva s podtitulem: Lawmaking in the area of environmental protection: The role of the international community, the European Union, states or self-government?

1 Evropa 2002, Evropa 2030, Evropa 2050. 
do energetického mixu a nikdo si není jistý, kdo by měl nést náklady.“ Základy pro budoucí energetickou unii jsou však vytvářeny již nyní, prostřednictvím nástrojů, které jsou $\mathrm{k}$ dispozici ve stávajících mantinelech a bez změny primárního práva EU. ${ }^{2}$ Cílem tohoto článku je stručně představit poslední výsledky evropského legislativního procesu, tzv. zimní balíček, zejména se zaměřením na aktivního spotřebitele a kapacitní mechanismy, a vše toto uvést do patřičných souvislostí. V závěru článku se objevuje krátké zamyšlení se nad vhodným způsobem zapracování změn do českého právního řádu a postoji k budované energetické unii.

\section{VÝVOJ OD ROKU 1992}

Od přijetí první liberalizační směrnice ${ }^{3}$ v roce 1992 uběhlo letos již 27 let. Za tu dobu došlo ve věci energetického trhu, přístupu ke službám v energetice a důležitosti zajištění energetické bezpečnosti k obrovskému posunu. Od roku 2004 jsou předpisy upravující energetiku vydávány ve formě tzv. balíčků (II. balíček 2004, III. „liberalizační“ balíček 2007, klimatický balíček 2008), které v sobě zahrnují změny nejvýznamnějších energetických směrnic a nařizení. Kromě samotného vývoje energetického trhu, snahu o jeho maximální propojení ve smyslu vytváření jednotného trhu, došlo postupně k prolínání klimatické politiky EU do tohoto, z hlediska produkce skleníkových plynů, klíčového odvětví. Klimatické závazky EU se prolínají na úrovni koncepčních ${ }^{4}$ dokumentů Evropa 2020, Evropa 2030 či Roadmap: Evropa 2050, a dále též plynou z mezinárodních závazků EU. Evropská unie je smluvní stranou Pařížské dohody z roku 2015, přičemž pro splnění cílů dohody, tedy nepřekročení průměrné globální teplotní změny $\mathrm{o}+2{ }^{\circ} \mathrm{C}$ má dojít primárně prostřednictvím snížení emisí skleníkových plynů. Mechanismus, prostřednictvím kterého má ke snižování emisí dojít, jsou tzv. vnitrostátně stanovené příspěvky, ${ }^{5}$ které právně vychází z článku 4 Pařížské dohody a předpokládá se, že všechny členské státy při stanovování výše příspěvků (tedy množství snížení), budou tyto stanovovat ambiciózně (článek 3). Otázka jejich nastavení za EU je řešena jednotně, má původ v článku 20, kdy EU je z hlediska terminologie Dohody „organizací regionální hospodářské integrace“, a tedy podle odst. 2 čl. 20, věty druhé „V prípadě organizace regionální hospodářské integrace s jedním nebo více členskými státy, které jsou smluvními stranami této dohody, rozhodne taková organizace a její členské státy o tom, jak si rozděli odpovědnost za plnění závazkủ podle této dohody. V takových připadech tato organizace a její členské státy nebudou oprávněny uplatňovat práva podle této dohody souběžně."

2 Tedy bez reformy článku 192 SFEU.

3 Směrnice Evropského parlamentu a Rady 96/92/ES ze dne 19. prosince 1996 o společných pravidlech pro vnitřní trh a elektřinu.

4 Byt' o jejich povaze lze diskutovat.

5 V originále dohody se používá termín NDCs - Nationally Determined Contributions. Originální znění anglického textu úmluvy [online] [3. 6. 2019], dostupné na: https://unfccc.int/files/meetings/paris_nov_2015 /application/pdf/paris_agreement_english_pdf.

6 Pařižská dohoda v českém překladu [online] [3. 6. 2019], dostupné na: https://www.mzp.cz /C1257458002F0DC7/cz/parizska_dohoda/\$FILE/OEOK-Cesky_preklad_dohody-20160419.pdf. 
Tyto cíle se tak prolnuly do strategie Evropa $2030,{ }^{7}$ která se následně upravila právě prostřednictvím zimního energetického balíčku.

\section{ZIMNÍ ENERGETICKÝ BALÍČEK}

„Čistá energie pro všechny Evropany“, je název zatím posledního, IV. energetického balíčku. Soubor legislativních dokumentů je též znám pod názvem „zimní energetický balíček“ a po svém březnovém schválení v evropském parlamentu byl schválen Evropskou radou 23. 5. 2019. ${ }^{8}$ Po stránce předpisů, kterých se dotýká, se balíček skládá z:

- revidovaného Nařizení evropského parlamentu a rady o vnitřním trhu s elektřinou,

- revidovaného Nařízení evropského parlamentu a rady o zrrízení Agentury Evropské unie pro spolupráci energetických regulačních orgánů,

- Nařizení evropského parlamentu a rady o rizikové připravenosti v odvětví elektřiny a zrušení směrnice 2005/89/ES,

- Směrnice Evropského parlamentu a rady o společných pravidlech pro vnitřní trh s elektrrinou a o změně směrnice 2012/27/EU, ${ }^{9}$

- Nařízení evropského parlamentu a rady 2018/1999 ze dne 11. prosince 2018, o správě energetické unie a opatření v oblasti klimatu, kterým se mění nařízení Evropského parlamentu a Rady (ES) č. 663/2009 a (ES) č. 715/2009, směrnice Evropského parlamentu a Rady 94/22/ES, 98/70/ES, 2009/31/ES, 2009/73/ES, 2010/31/EU, 2012/27/EU a 2013/30/EU, směrnice Rady 2009/119/ES a (EU) 2015/652 a zrušuje nařízení Evropského parlamentu a Rady (EU) č. 525/2013,

- Směrnice evropského parlamentu a rady 2018/844 ze dne 30. května 2018, kterou se mění směrnice 2010/31/EU o energetické účinnosti budov a směrnice 2012/27/EU o energetické účinnosti,

- revidovaná Směrnice evropského parlamentu a rady 2018/2001 ze dne 11. prosince 2018, o podpoře využívání energie $\mathrm{z}$ obnovitelných zdrojů,

- Směrnice evropského parlamentu a rady 2018/2002 ze dne 11. prosince 2018, kterou se mění směrnice 2012/27/EU o energetické účinnosti, (dále jen „,revidovaná směrnice o energetické účinnosti“"). ${ }^{10,11}$

7 Ty původně předpokládaly, že do roku 2030 dojde ke snižení emisí skleníkových plynů o $40 \%$ oproti roku 1990, energetická účinnost se zvýší na $30 \%$ a podíl energie vyrobené z obnovitelných zdrojů bude $27 \%$.

8 VRBOVÁ, Z. Čtvrtý energetický balíček oficiálně schválen [online] [5. 6. 2019] dostupné na: https:// oenergetice.cz/evropska-unie/ctvrty-energeticky-balicek-oficialne-schvalen/.

9 Uvedené akty čekají nyní na svou publikaci v Ưredním věstníku Evropské unie.

${ }^{10}$ Clean energy for all Europeans, oficiální stránky Evropské komise [online] [5. 6. 2019], dostupné na: https://ec.europa.eu/energy/en/topics/energy-strategy-and-energy-union/clean-energy-all-europeans.

11 Př́ípadně by bylo možné pro úplnost jako relevantní dokumenty k zimnímu energetickému balíčku (byt' jádro je tvořené výčtem výše) přiřadit ještě dva z oblasti ekodesignu, a sice Sdělení komise: Pracovní plán pro ekodesign na období 2016-2019, COM (2016) 773 a Nařízení Komise 2016/2281 ze dne 30. listopadu 2016, kterým se provádí směrnice Evropského parlamentu a Rady 2009/125/ES o stanovení rámce pro určení požadavků na ekodesign výrobků spojených se spotřebou energie, pokud jde o požadavky na ekodesign ohřívačů vzduchu, chladicích zařízení, vysokoteplotních procesních chladičů a ventilátorových konvektorů 
Tento impozantní výčet legislativy zimního energetického balíčku se dá shrnout i do několika čísel a pojmů, umožňujících si představit budoucí vývoj evropské energetiky. Nejprve co se týče čísel, v důsledku jeho přijetí došlo k revizi klimatických cílů po roce 2020, kdy v absolutních číslech by mělo dojít k navýšení procentuálního zastoupení ve všech klíčových oblastech. Závazně tedy by mělo dojít k zvýšení energetické účinnosti na $32,5 \%$ a podílu výroby z obnovitelných zdrojů na úrovni $32 \%$. V důsledku toho je předpokládáno též snížení emisí skleníkových plynů, odhadované na $45 \%$ oproti roku 1990. V obecné rovině směřování je zimní energetický balíček dokumentem, který nás má posunout k decentralizované, uhlík opouštějící, odolnější a pro zákazníky příznivější energetice.

\section{AKTIVNÍ ZÁKAZNÍK}

V souvislosti s přijetím balíčku je třeba se věnovat i některým českému právu dosud neznámým nebo nepř́liš použivaným pojmům. První z nich je prosumer, kombinace spotřebitele (consumer) a výrobce (producer), prričemž do češtiny je předkládán jako aktivní zákazník. Z hlediska definice dle čl. 2 bodu 8) Směrnice o společných pravidlech pro trh s elektřinou, se jedná o: „konečného zákazníka nebo skupinu společnějednajících konečných zákazníkư, kteři spotřebovávají nebo skladuji elektřinu vyrobenou ve svých vlastnich prostorách umistèných ve vymezených hranicich, anebo pokud to členský stát povolí, v jiných prostorách, nebo kteři prodávají elektřinu vyrobenou z vlastnich zdrojü, či se účastní programů flexibility nebo energetické účinnosti, za predpokladu, že uvedené činnosti nepředstavuji jejich hlavní obchodni nebo profesionální činnost".

Věcně se jedná o zákazníka, který si pořídil svou vlastní výrobnu, díky které má částečnou energetickou soběstačnost, ovšem nesmí se jednat o jeho hlavní obchodní činnost. Zajímavé na uvedeném konstruktu je, že do této kategorie spadnou jak ti, kteří přebytky své produkce prodávají na energetickém trhu, stejně jako ty, kteří ji pouze skladují a spotřebovávají bez možnosti dalšího prodeje (typicky solární instalace s bateriovým úložǐštěm). Dále to, že se může jednat i o skupinu jednající společně, tedy určité energetické společenství. Kromě aktivních zákazníků, se novinky týkají samozřejmě též zákazníků klasických, kdy je snaha o jejich co největší zapojení do služeb a umožnění čerpání co nejvíce benefitů energetického trhu. Tomu ostatně odpovídá i znění bodu 39 důvodů príjetí směrnice, který uvádí: „Všechny skupiny zákazníků... by měly mít přistup na trhy s energií za účelem obchodováni se svou flexibilitou a elektřinou vyrobenou z vlastnich zdrojü. Zákazníci by měli mit možnost plně využivat výhod agregace výroby a dodávek ve většich regionech a mít užitek z preshraniční hospodářské soutěže. Účastníci trhu vykonávající služby agregace budou mit pravděpodobnè důležitou úlohu jako prostředníci mezi skupinami zákazníků a trhem. Členské státy by měly mít možnost zvolit si pro účely nezávislé agregace vhodný model provádění řizení, přičemž by měly dodržovat obecné zásady stanovené v této směrnici. Takový model nebo přistup by mohl zahrnovat výběr tržnich nebo regulačnich zásad, jež poskytují řešení pro účely dodržováni této směrnice, včetně modelü, v jejichž rámci se zúčtovávaji odchylky nebo 
zaváděny úpravy diagramu spotřeby. Zvolený model by měl obsahovat transparentní a spravedlivá pravidla, aby nezávislí agregátoři mohli plnit úlohu prostředníkủ a aby bylo zajištěno, že konečný zákaznik bude mit z jejich činnosti odpovídajici prospěch. Produkty by měly být definovány pro všechny trhy, včetně trhů s podpůrnými službami a kapacitou, aby se stimulovala účast odezvy strany poptávky. "Typickým př́íladem změny ve prospěch spotřebitele je umožnění zákazníkům uzavírat smlouvy s dynamickým určováním ceny elektřiny, kdy se jedné o „,smlouvu na dodávky elektřiny mezi dodavatelem a konečným zákazníkem, která odráži cenové změny na spotových trzích včetně denních a vnitrodenních trhův v intervalech odpovídajicich přinejmenším četnosti vypořádáni tržních transakci" (čl. 2 bod 15 Směrnice o společných pravidlech pro trh s elektř̌inou). Vhodné nastavení takových dodávek může pro spotřebitele znamenat úspory za spotřebovanou energii a může pomoci co nejlepšímu vybalancování trhu. ${ }^{12}$ Pro umožnění výše uvedených služeb je samozřejmě nutné zapojovat do sítě co nejvíce nové technologie jako je smart metering s cílem vytvořit celé chytré sítě (smart grids) s možností vzdálené kontroly jak produkčních, tak spotřebních míst (remote control).

\section{KAPACITNÍ MECHANISMY}

Druhým a z hlediska specializace autora na právo životního prostředí klíčovým pojmem, jsou kapacitní mechanismy vycházející z potřeby zajištění dodávek elektřiny i v př́ípadě, kdy nejsou optimální podmínky pro její produkci ze zdrojů obnovitelných. Shrnuto, zda má stát (případně i se sousedními státy) dostatečnou zdrojovou přiměřenost i za předpokladu, že vypadnou dodávky zdrojů obnovitelných. Zdroje, které jsou schopny poměrně rychle poskytnout požadovaný výkon, jsou nejčastěji tepelné elektrárny na úhlí a zemní plyn. $V$ čl. 23 odst. 2 a 3 Nařízení o společném trhu je uvedeno: „(2). Před zavedením kapacitnich mechanismů provedou dotčené členské státy komplexní studii možných dopadů těchto mechanismů na sousední členské státy alespoň prostřednictvím konzultace se sousedními členskými státy, s nimiž maji př́mé sitové propojení, a se zainteresovanými subjekty těchto členských států. (3). Členské státy posoudí, zda potiže se zdrojovou priměreností může řešit kapacitni mechanismus $v$ podobě strategické rezervy. Pokud tomu tak není, mohou členské státy zavést jiný typ kapacitního mechanismu.“ Zde je nutné uvést, že zavádění kapacitních mechanismů podléhá dle čl. 20 odst. 5 ve spojení s čl. 23 odst. 1 Nařízení o společném trhu posouzení zdrojové přiměřenosti Evropskou komisí. ${ }^{13}$

Zásady, které je nutné dodržovat při vytváření kapacitních mechanismů, jsou obsaženy v čl. 21 a čl. 22 Nařízení o společném trhu. Jedná se zejména o jejich dočasnost, nenarušování trhu, nepřekračování rámce nutného $\mathrm{k}$ řešení problémů, vybírání

12 Zde je třeba si uvědomit, že pro efektivní fungování evropské energetické sítě (a na ní napojeného trhu) je třeba udržovat rovnováhu v přenosové soustavě tak, aby výroba a spotřeba energie byly v rovnováze. Díky navyšujícímu se podílu obnovitelných zdrojů na produkci je tak vhodné mít nástroje, umožňující tržně na množství energie v síti reagovat.

${ }^{13}$ Kdy kritérii posouzení jsou: posouzení soustavy z hlediska stávajicich dodávek elektřiny a předpokládané poptávky po ní na úrovni Unie, na úrovni členských států a tam, kde je to relevantní, na úrovni nabídkových zón. (čl. 23 odst. 1 Nařízení o společném trhu). 
poskytovatele kapacity transparentním, nediskriminačním a konkurenčním zpơsobem umožňujícím účast všech druhů zdrojů. Poslední jmenovaná podmínka zavádí určitou technologickou neutrálnost. Ta je však částečně kompenzována v rámci zohlednění klimatických cílů, kdy kritikové kapacitních mechanismů uváděli, že umožňují udržovat v provozu i staré ale levné fosilní zdroje, které by jinak již byly odstaveny. ${ }^{14}$ Kompenzace je zakotvena v čl 22 odst. 4, který zavádí omezení prostřednictvím mezních hodnot následujícím způsobem:

„a) výrobní kapacity s emisemi $\mathrm{CO}_{2}$ z fosilních paliv vyššimi než $550 \mathrm{~g}$ na $\mathrm{kWh}$ elektřiny, které zahájily komerční výrobu dne ... [den vstupu tohoto nařízení v platnost] nebo později, nesmějí nejpozději od tohoto dne v rámci kapacitního mechanismu být zařazovány ani obdržet platby ani závazky $k$ dalším platbám;

b) výrobni kapacity s emisemi $\mathrm{CO}_{2}$ z fosilních paliv vyššimi než $550 \mathrm{~g}$ na kWh elektřiny a zároveň s emisemi $\mathrm{CO}_{2}$ z fosilních paliv vyššími než $350 \mathrm{~kg}$ na instalovaný $\mathrm{kW}$ elektrického výkonu v ročním průměru, které zahájily komerční výrobu před ... [den vstupu tohoto nařízení v platnost], nesměji nejpozději od 1. července 2025 v rámci kapacitního mechanismu být zařazovány ani obdržet platby ani závazky k dalším platbám. Mezni hodnota emisi $\mathrm{CO}_{2}$ z fosilních paliv $550 \mathrm{~g}$ na $\mathrm{kWh}$ elektřiny a mezní hodnota emisí $\mathrm{CO}_{2}$ z fosilních paliv $350 \mathrm{~kg}$ na instalovaný $\mathrm{kW}$ elektrického výkonu v ročním prüměru uvedená v prvním pododstavci písm. a) a b) se vypočitá na základě projektované účinnosti výrobni jednotky, kterou se rozumí čistá účinnost při jmenovité kapacitě podle př́slušných norem Mezinárodní organizace pro normalizaci.“

Pozornému čtenáři jistě neuniklo, že se v textu autor zabývá pouze základními mantinely kapacitních mechanismů a že z citovaných ustanovení přímo plynou některé z nich. Vzhledem k omezenému rozsahu článku se tak prosím spokojme s konstatováním, že základními mechanismy jsou kapacitní platby, jejichž podmnožinou jsou platby za strategické rezervy, přičemž v jejich případě cenu za kWh poptávané elektřiny nabídne objednatel a čeká, jaký efekt bude tato nabídka mít. Alternativou, je tzv. kapacitní trh, kdy je to naopak - „stát nebo jiná instituce určí, kolik kapacit by se mélo zajistit (centralizovaná varianta), nebo pro to stanoví vzorec (decentralizovaná varianta), a trh pak určí, kolik to bude stát "“. ${ }^{15} \mathrm{~V}$ současné době nejsou v České republice kapacitní mechanismy aplikovány.

\section{DALŠÍ NOVINKY STRUČNĚ}

Další novinky vyplývající z energetického balíčku jsou spojeny s úpravou kodexů přenosových sítí, posílení role Agentury Evropské unie pro spolupráci energetických regulačních orgánů a národních regulátorů, včetně zvýšení prvků energetické bezpečnosti a daleko vyšších nároků na vzájemné vybalancování všech systémů. Ve vý-

14 Na skupování fosilních elektráren na hraně životnosti a využívání kapacitních mechanismů je např́íklad z podstatné části postaven obchodní model společnosti EPH.

15 KUČERA, J. Elektrárenský gordický uzel III: Mechanismus zvaný kapacitní [online] [7. 6. 2019], dostupné na: http://ceskapozice.lidovky.cz/elektrarensky-gordicky-uzel-iii-mechanismus-zvany-kapacitni-pt9 -/tema.aspx?c=A150605_133845_pozice-tema_kasa. 
čtu můžeme pokračovat slovy digitalizace, chytrá měřicí zařízení, chytré spotřebiče, vše dohromady vytvářející chytré sítě co nejlépe využívající aktuální výrobu, optimalizující spotřebu a akumulující nespotřebovanou energii. V souvislosti s akumulací je třeba zmínit předpoklad, že akumulační zařízení ani dobíjecí infrastrukturu nebude vlastnit provozovatel distribuční soustavy. Tedy opětovné oddělení vlastnictví tak, jak je již známé v rámci unboundingu výrobců a distributorů.

\section{7. ČESKÁ PRÁVNÍ ÚPRAVA A POZICE}

Základy českého energetického práva jsou vtěleny do tř́i zákonů, zákona č. 458/200 Sb., o podmínkách podnikání a o výkonu státní správy v energetických odvětvích (dále jen ,energetický zákon“), zákona č. 165/2012 Sb., o podporovaných zdrojích energií a zákona č. 406/2000 Sb., o hospodaření energií. Všechny uvedené předpisy byly opakovaně novelizovány, přičemž kromě zákona o podporovaných zdrojích energií, oslaví dva zbývající v prríštím roce 20. výročí od svého přijetí. Je otázkou, zda by si tato část právního řádu České republiky nezasloužila novou právní úpravu, reagující pružněji na technologický vývoj a pravděpodobný rozvoj dalšího sektoru ekonomiky v souvislosti s poskytováním služeb v energetice. Přestože širší odborná veřejnost sleduje zprávy o otevírání bateriových úložišt' ve vzdálených státech i okolních státech EU, málokdo si uvědomuje, že komerční provoz takových zařízení v ČR není z důvodu technické zaostalosti, ale chybějící právní úpravy jejich komerčního provozování. Což je zřejmě jeden z nejmarkantnějších nedostatků stávajícího energetického zákona, nicméně dalších př́kladů by šlo nalézt celou řadu. Je tedy otázkou, zda namísto novelizace mnohokrát novelizovaného předpisu nepřejít k sepsání celého nového, moderního energetického zákona. Podle autora jednoznačně ano.

Stav energetických zákonů poměrně značně determinuje též stávající Státní energetická koncepce, která je však založena na východiscích před přijetím Pařížské úmluvy a zimního energetického balíčku. Její aktualizace se v důsledku změn pojetí energetiky v EU, jeví jako logický krok. Její součástí by měla jednoznačně být konkretizace českých postojů v rámci vznikající energetické unie a ze strany vlády by mělo dojít k rozhodnutí, jak bude vypadat energetický mix ČR v př́štích desetiletích.

Závěrem si dovolím zcela věcné zamyšlení, které plyne z ekonomické náročnosti připravovaných změn a od toho se odvíjející jejich akceptace veřejností. Dá se očekávat, že v souvislosti s integrací nových zařízení, služeb a v obecné rovině požadavků kladených na provozovatele přenosové soustavy ${ }^{16}$ leckoho napadne otázka financování probíhajících změn. Aktuální předklady jsou založeny na dispozici dostatečnými prostředky provozovatelů distribuční soustavy. Přestože autor článku nepochybuje o profitabilitě provozování distribučních sítí, je otázka, jak moc prostředky investované nad rámec běžné údržby sítí v rámci životnosti jednotlivých komponent v konečném důsledku pocítí spotřebitelé. Ti by tak mohli platit sice méně za samotné odebrané množství energií (o jejichž ceně nechce autor spekulovat, ale očekává spíše růst), nicméně by se zvýšily

16 Které jsou mnohonásobně technicky náročnější. 
poplatky za distribuci. S tím dále souvisí otázka fázování jednotlivých změn, a jak uvádí Ing. Pavel Šolc, člen představenstva ČEZ distribuce a.s.: „Cesta k decentralizované energetice je zdlouhavá a nákladná. Nelze očekávat, že energetický systém, který je výsledkem více než stoletého vývoje a prưměrné stárí zařizení je okolo 40 let, lze totálně změnit během několika let." 17 Jaká bude realita dalšího vývoje evropské energetiky po implementaci zimního energetického balíčku, uvidíme nejpozději v roce 2030.

JUDr. Jiří Pokorný, Ph.D.

Právnická fakulta Univerzity Karlovy

pokornyj@prf.cuni.cz

17 ŠOLC, P. Minulost, př́tomnost a budoucnost české energetiky z praktického pohledu. Přednáška v rámci předmětu Horní, energetické, atomové právo; PF UK, 11. 5. 2019. 